\title{
Genetic diversity and population structure of endangered rosewood from the Peruvian Amazon using ISSR markers
}

\author{
Stalin Juan Vasquez GUIZADO ${ }^{1,2}$, Muhammad Azhar NADEEM ${ }^{3}$, Fawad ALI ${ }^{4,5}$, Muzaffer BARUT ${ }^{4,6}$, Ephrem \\ HABYARIMANA ${ }^{7}$, Tedi Pacheco GÓMEZ ${ }^{1}$, Jhon Antoni Vargas SANTILLAN ${ }^{2}$, Esperanza Torres CANALES ${ }^{1}$, \\ Juan Carlos Castro GÓMEZ², Gyuhwa CHUNG ${ }^{*}$, Faheem Shehzad BALOCH ${ }^{3,4^{*}}$ (1) \\ Universidad Nacional de la Amazonía Peruana, Facultad de Ciencias Forestales, Departamento de Conservación de Recursos Naturales, Iquitos 16001, Peru \\ Universidad Nacional de la Amazonía Peruana, Centro de Investigación de Recursos Naturales de la Amazonía, Unidad Especializada de Biotecnología, lquitos 16001, Peru \\ Sivas University of Science and Technology, Faculty of Agricultural Sciences and Technologies, Sivas 58140, Turkey \\ ${ }^{4}$ Bolu Abant Izzet Baysal University, Faculty of Agricultural and Natural Science, Department of Field Crops, Bolu 14100, Turkey \\ Quaid-I- Azam University, Department of Plant Sciences, Islamabad 45710, Pakistan \\ 6 University of Çukurova, Faculty of Agriculture, Department of Field Crops, Balcall, Adana, Turkey \\ CREA - Centro di Ricerca Cerealicoltura e Colture Industriali, via di Corticella 133, 40128 Bologna, Italy \\ ${ }^{8}$ Chonnam National University, Department of Biotechnology, Chonnam 59626, Korea \\ * Corresponding author: chung@chonnam.ac.kr, balochfaheem13@gmail.com; (10 https://orcid.org/0000-0002-7470-0080
}

\begin{abstract}
Rosewood, Aniba rosaeodora is an endangered species in Amazon forests and its natural stands have been heavily depleted due to over-exploitation for the cosmetic industry. This study aimed to investigate the genetic diversity and population structure of 90 rosewood accessions from eight localities in the Peruvian Amazon through 11 Inter Simple Sequence Repeats (ISSR) primers. The ISSR primers produced a sum of 378 bands, of which 375 (99.2\%) were polymorphic, with an average polymorphism information content (PIC) value of 0.774 . The mean effective number of alleles (Ne), Shannon informative index (I), gene diversity $(\mathrm{He})$ and total gene diversity $(\mathrm{Ht})$ were $1.485,0.294,0.453$ and 0.252 , respectively. Analysis of molecular variance (AMOVA) showed the presence of maximum variability within populations (88\%). The Structure algorithm, neighbor joining and principal coordinate analysis ( $\mathrm{PCoA}$ ) grouped the 90 rosewood accessions into three main populations (A, B and C). Diversity indices at the inter-population level revealed a greater genetic diversity in population $\mathrm{A}$, due to higher gene flow. The neighbor-joining analysis grouped populations $\mathrm{A}$ and $\mathrm{B}$, while population $\mathrm{C}$ was found to be divergent at the inter population level. We concluded that population A reflects higher genetic diversity and should be prioritized for future management and conservation plans.
\end{abstract}

KEYWORDS: Aniba rosaeodora, endangered species, gene flow, germplasm, molecular characterization

\section{Diversidad genética y estructura poblacional de palo de rosa en peligro de extinción de la Amazonía Peruana utilizando marcadores ISSR}

\section{RESUMEN}

Palo de rosa, Aniba rosaeodora es una especie en peligro de extinción en los bosques amazónicos. Sus rodales naturales se han agotado debido a la sobreexplotación para la industria cosmética. Este estudio tuvo como objetivo investigar la diversidad genética y estructura poblacional de 90 accesiones de palo de rosa de ocho localidades en la Amazonía Peruana utilizando 11 marcadores de Inter Secuencias Simples Repetidas (ISSR). Los marcadores ISSR produjeron una suma de 378 bandas, de las cuales 375 (99,2\%) fueron polimórficas, con un valor promedio de contenido de información de polimorfismo (PIC) de 0,774. El promedio del número efectivo de alelos $(\mathrm{Ne})$, índice informativo de Shannon (I), diversidad genética $(\mathrm{He})$ y diversidad genética total $(\mathrm{Ht}$ ) fueron 1,485; 0,294; 0,453 y 0,252; respectivamente. El análisis de varianza molecular (AMOVA) mostró la presencia de máxima variabilidad dentro de las poblaciones (88\%). El algoritmo Structure, neighbor joining y análisis de coordenadas principales ( $\mathrm{PCoA}$ ) agruparon las 90 accesiones de palo de rosa en tres poblaciones principales (A, B y C). Los índices de diversidad a nivel interpoblacional revelaron una mayor diversidad genética en la población $\mathrm{A}$, debido al mayor flujo de genes. El análisis de neighbor joining agrupó las poblaciones A y B, mientras la población C fué divergente a nivel interpoblacional. Concluimos que la población A refleja mayor diversidad genética y debería priorizarse para futuros planes de manejo y conservación.

PALABRAS-CLAVE: Aniba rosaeodora, especies en peligro de extinción, flujo de genes, germoplasma, caracterización molecular

CITE AS: Guizado, S.J.V.; Nadeem, M.A.; Ali, F.; Barut M.; Habyarimana, E.; Gómez, T.P.; Santillan, J.A.V.; Canales, E.T.; Gómez, J.C.C.; Chung, G.; Baloch, F.S. 2020. Genetic diversity and population structure of endangered rosewood from the Peruvian Amazon using ISSR markers. Acta Amazonica 50: $204-212$. 


\section{INTRODUCTION}

The first global assessment of plant extinction risk indicated that every fifth plant species in the world is threatened with extinction (Ibrahim et al. 2013). The Amazon region represents one of the richest reservoirs of biological diversity on the planet (Confalonieri et al. 2014; Gentry 1992), and is considered a biodiversity hotspot that can serve as a potential source of genetic variability for breeding perspectives of crops (Myers et al. 2000; Gentry 1992). Rosewood, Aniba rosaeodora Ducke (Lauraceae) has $2 \mathrm{n}=24$ chromosomes (Contim et al. 2005), and is distributed in the Amazon region of Brazil, Guyana, Suriname, Peru, Colombia, and Venezuela (Maia and Mourão 2016). The species is known for its essential oil, which is mainly characterized by a high content of linalool in the leaves and branches (74.4-81.8\%) (Pimentel et al. $2018)$ and in the trunk wood $(-100 \%)$ (Chantraine et al. 2009). Rosewood essential oil was extracted at a large scale from 1875 to 1975 in French Guiana, and trees were felled in such proportions that natural populations were significantly depleted (Bruleaux 1989). Export of rosewood essential oil has undergone a significant decline since 2001, and French Guiana banned the felling of this tree. Currently, Brazil is the only producer of rosewood essential oil (Amusant $e t$ al. 2015). Rosewood is now included as an endangered species in the database of the Convention on International Trade in Endangered Species of Wild Fauna and Flora (Salazar 2011).

Rosewood trade in Peru started in 1941, when Samuel Reggeroni, owner of the Pucabarranca farm on the Napo River, sent his first essential oil samples to Europe (MINAM 2015). During the 1950s, an increase in trade of rosewood essential oil was observed globally (MINAM 2015; Krainovic et al. 2017), reaching 300 tones year ${ }^{-1}$ in Brazil. In Peru, rosewood forests are located north of the Marañon - Amazonas river axis, along the rivers Tiger, Napo and Putumayo (MINAM 2015). It is believed that rosewood populations were greatly reduced by historical exploitation, fragmentation of habitats and deforestation resulting from the extraction of species of high timber value (Salazar 2011). Currently, rosewood is categorized as vulnerable in Peru (Salazar 2011), therefore the Peruvian government has taken strong actions to halt the decline of the species, and the export of rosewood wood and essential oil is forbidden since 1972. The Peruvian ministry of agriculture recommended the establishment of rosewood plantations in order to promote the conservation of the species in the wild and its commercial exploitation (Salazar 2011; MINAM 2015).

Studies on the genetic diversity and population structure of endangered species are necessary to design conservation and management strategies, including the selection of germplasm accessions for cultivation and improvement programs (Tabin et al. 2016; Ali et al. 2020a)commonly called Rhubarb, form an important component of the north western Himalayan flora and provide high value medicinal products to folks and pharmaceutical industries. Genetic diversity and structure of three Rheum species, namely, Rheum emodi, R. spiciforme and R. webbianum from Kashmir Himalaya was examined at the molecular level using Inter-Simple Sequence Repeat (ISSR. Characterization of wild germplasm is a necessary step to determine intraspecific variability for use in the design of breeding programs for plant species (Barut et al.2020; Nadeem et al. 2020). Molecular markers have been very helpful in investigating genetic diversity, and exploring the genetic relationship among the genotypes of various crops (Yaldiz et al. 2018; Yildiz et al. 2019; Karı et al. 2019). Various types of molecular markers have been developed according to their application efficiencies (Nadeem et al. 2018). Studies have confirmed that ISSR are abundant and widely distributed throughout plant nuclear genomes (González et al. 2007; Ekincialp et al. 2019; Nadeem et al. 2018) and have been successfully utilized for the assessment of population structure and genetic variation in various crop species (Cardoso et al. 2019; Ekincialp et al. 2019; Ali et al. 2020b).

In the case of rosewood, current efforts are being made globally to bring sustainability to the rosewood essential oil industry through in-situ and ex-situ germplasm collections (Amusant et al. 2016). Most studies on the species have been about the activity of its essential oil (Sarrazin et al. 2016; Amusant et al. 2016; Maia and Mourão 2016). Information about the genetic characterization of rosewood using molecular markers and its conservation management is available for populations in Brazil (Santos et al. 2004, Santos et al. 2008a, b; Angrizani et al. 2013), but is lacking for rosewood in Peru. There is no ex situ germplasm bank for this species in Peru, and the information available in Peruvian Amazonian herbaria on this species is limited. Therefore, the objective of this study was to investigate the genetic diversity and population structure of rosewood from remnants in the Peruvian Amazon using 11 ISSR primers.

\section{MATERIAL AND METHODS}

\section{Plant material and DNA extraction}

For this study, we collected leaves of 90 rosewood trees from eight different localities in the regions of Loreto and Ucayali, in the Peruvian Amazon (Figure 1; Supplemental Material, Table S1), which are considered main habitats for rosewood in Peru. Three localities are close to Iquitos, two of them accessible by road, and one on the margin of the Amazonas River (Figure 1). The rosewood population in the locality of Allpahuayo is adjacent to the AllpahuayoMishana National Reserve. The populations in Zungarococha, Mayriricay, Nanay, Tamshiyacu and Santa Marta are located within private estates, and those in Huajoya and Maria de Huajoya, within native community lands. The Instituto de Investigaciones de la Amazonía Peruana (IIAP) established a 
pilot plantation of rosewood 25 years ago in the perimeter zone of the Allpahuayo National, Reserve. The populations in Zungarococha, Allpahuayo and Mairirircay are plantations from material originating from Tamshiyacu. The plantations are 25,20 and 15 years old, respectively.

For the extraction of genomic DNA, leaves of each accession were packaged separately and kept on ice to avoid oxidation, and were transported to the laboratory of the specialized unit of biotechnology of the Centro de Investigación de Recursos Naturales de la Amazonía, in Iquitos, Peru. Species identification was based on the morphology of the collected material and was carried out at the Herbarium Amazonence of Universidad Nacional de la Amazonía Peruana (Iquitos, Peru). Leaves of each accession were kept in a freezer at -20 ${ }^{\circ} \mathrm{C}$ until isolation of the genomic DNA, which followed the protocol suggested by Castro et al. (2017). DNA was diluted in TE (Tris-EDTA) with a final volume of $35 \mu \mathrm{L}$ per accession, and then stored at $-20^{\circ} \mathrm{C}$. Genomic DNA quantification was performed by spectrophotometry using Nanodrop 2000c (Thermo Scientific, USA).

\section{ISSR primer analysis}

A total of 70 ISSR primers were screened using eight randomly selected rosewood accessions for PCR amplification. Out of the 70 ISSR primers, 11 most polymorphic primers were selected and used for the final PCR amplification, which resulted in high polymorphism with strong and clear band profiles, suitable for genotyping of all accessions (Table 1). A total reaction volume of $25 \mu \mathrm{L}$ for PCR amplifications was comprised of $25 \mathrm{ng}$ of template DNA, $4 \mu \mathrm{L}$ dNTPs $(0.2$ $\mathrm{mM}$ ) (Thermo Scientific), $0.2 \mu \mathrm{L}$ U Taq DNA polymerase (Thermo Scientific), $1 \mathrm{mM}$ primer , $2.5 \mu \mathrm{L} 1_{\mathrm{X}}$ PCR buffer (Thermo Scientific), $2 \mathrm{mM} \mathrm{MgCl}_{2}$ and $11.3 \mu \mathrm{L}$ distilled water.
Reactions were performed in the sequence of denaturation at $94^{\circ} \mathrm{C}$ for $3 \mathrm{~min}$, followed by 30 denaturation cycles at $94^{\circ} \mathrm{C}$ for $1 \mathrm{~min}$, annealing temperature of $48-54^{\circ} \mathrm{C}$ for one minute, depending upon the primer, and a final extension for $10 \mathrm{~min}$ at $72{ }^{\circ} \mathrm{C}$. Agarose gel $1.8 \%(\mathrm{w} / \mathrm{v})$ containing $0.5 \mathrm{x}$ Tris-borateEDTA (TBE) buffer was used for the electrophoreses of the amplified DNA fragments at a constant voltage of $120 \mathrm{~V}$ for $240 \mathrm{~min}$. Ethidium bromide was used to perform the staining of the gel and Gel Doc XR+ system (Bio-Rad, USA) was used as gel imager to visualize the gel and to take photographs. Two $\mu \mathrm{l}$ of the $100 \mathrm{bp}+$ molecular weight marker was used for the measurement of the fragment patterns (Promega, Madison, South Dakota, USA).

\section{Statistical analysis}

ISSR bands (strong, clear, and unambiguous) were manually scored using the binary system as present (1) versus absent (0). The following genetic diversity indices were calculated by using PopGene ver. 1.32: effective allele number $(\mathrm{Ne})$, Shannon's Information Index (I), gene diversity $(\mathrm{He})$ and the overall gene diversity $(\mathrm{Ht})$. Polymorphism information content (PIC) was calculated as suggested by Baloch et al. (2015) genetic studies in lentil are still in their infancy. Genetic diversity and relationships among wild Lens species from Turkey has seldom been investigated. Additionally, a limited number of simple sequence repeat (SSR. To evaluate the genetic relationship among the 90 rosewood accessions, the pairwise genetic distance (GDj) (Jaccard 1908) was calculated using the jaccard package in the R statistical software. Analysis of molecular variance (AMOVA) and principal coordinate analysis (PCoA) were performed using GenAlEx v6.5 software (Peakall and Smouse 2012). A neighbor joining analysis was performed using the ape package in the $\mathrm{R}$ software. The

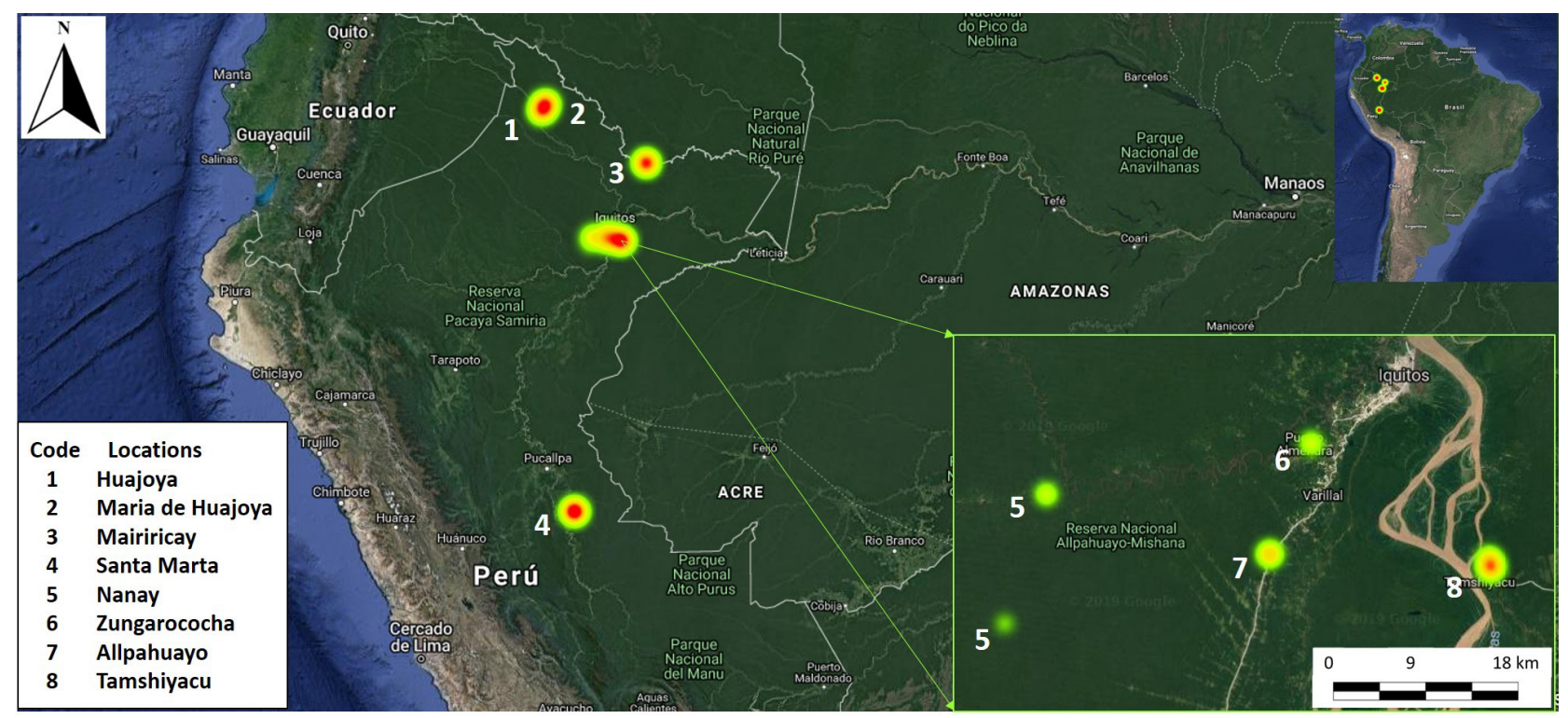

Figure 1. Collection localities of rosewood, Aniba rosaeodora accessions in the Peruvian Amazon. This figure is in color in the electronic version. 
Table 1. List of the 11 most polymorphic primers (sequences and annealing temperature) used for the assessment of the genetic diversity and population structure of rosewood, Aniba rosaeodora germplasm from the Peruvian Amazon.

\begin{tabular}{ccc}
\hline Primer & Sequence & $\begin{array}{c}\text { Annealing } \\
\text { temperature }\left({ }^{\circ} \mathrm{C}\right)\end{array}$ \\
\hline 807 & AGAGAGAGAGAGAGAGT & 50 \\
810 & GAGAGAGAGAGAGAGAT & 50 \\
812 & GAGAGAGAGAGAGAGAA & 50 \\
814 & CTCTCTCTCTCTCTCTA & 50 \\
815 & CTCTCTCTCTCTCTCTG & 52 \\
817 & CACACACACACACACAA & 50 \\
818 & CACACACACACACACAG & 52 \\
819 & GTGTGTGTGTGTGTGTA & 50 \\
\hline 826 & ACACACACACACACACAG & 52 \\
\hline 840 & AGAGAGAGAGAGAGAGYT & 52 \\
\hline
\end{tabular}

population structure was calculated using the STRUCTURE software (Evanno et al. 2005). The initial burn-in period was set to 5000 with 100,000 MCMC (Markov chain Monte Carlo) iterations with no prior information on the origin of individuals. For each $\mathrm{K}$ and each run, 10 independent runs were set as parameters to estimate the population structure. We plotted the cluster number $(\mathrm{K})$ against logarithm probability relative to standard deviation $(\Delta \mathrm{K})$ and the criteria by Evanno et al. (2005) were used to estimate the optimum number of clusters (K subpopulations). Each accession was assigned to its respective population on the basis of its membership coefficient being greater than or equal to $50 \%$ as suggested by Habyarimana (2016)assessment of GS strategies for grain yield improvement in this crop is still limited. This work aimed to evaluating the cross-validation accuracy (rcv. We calculated the same genetic diversity indices as above for the STRUCTURE populations using PopGene version 1.32. Gene flow among the STRUCTURE populations was also estimated following the methodology of Mallet (1999) and by performing the neighbor joining analysis using the ape package in the R software.

\section{RESULTS}

The eleven most polymorphic ISSR primers yielded a sum of 378 bands and 34.4 average bands per primer in the 90 accessions. Among the 378 scored bands, 375 (99.2\%) were polymorphic, with an average of 34.1 bands per primer (Table 2). Maximum (51) and minimum (10) number of bands resulted with primers ISSR826 and ISSR819, respectively. PIC averaged 0.774 , with minimum and maximum values of 0.592 (ISSR819) and 0.867 (ISSR834), respectively (Table 2). The average number of alleles was 1.485 , with maximum and minimum values of 1.608 (ISSR812) and 1.427 (ISSR840), respectively. The average value for the Shannon information index was 0.294 , with highest (0.356) and lowest (0.261) values resulting with ISSR812 and ISSR840, respectively (Table 2). The highest (0.532) level of gene diversity was recorded for ISSR812, and the lowest (0.406) for ISSR840, with an average of 0.453 .

The overall mean genetic distance among accessions was 0.554 , with a maximum distance of 0.83 between the Mairiricay- 11 and Santamarta- 4 accessions, and a minimum of 0.09 between Nanay- 4 and Nanay-5. The STRUCTURE analysis divided the accessions into three populations $(\mathrm{K}=3)$, with $29(32.2 \%)$ accessions in population A, 41 (45.6\%) in population B, and $20(22.2 \%)$ in population C (Figure 2). Population A was the genetically most diverse, comprising accessions from Nanay, Mariadehuajoya, Mairiricay and Huajoya (Figure 2). Population B, the largest, clustered accessions from Allpahuayo, Zunagarococha, Tamshiyacu and Mairiricay. Population $\mathrm{C}$ was the least diverse and clustered all 20 accessions from Santa Marta (Figure 2), the location farthest away from the other localities (Figure 1).

Population A had higher genetic diversity compared to the other two populations, as indicated by its high number of effective alleles (1.44), gene diversity (0.27), Shannon information index (0.41) and gene flow (2.875) (Table $3)$. Mean genetic distance within populations was 0.36 for population A, 0.323 for population $\mathrm{B}$, and 0.314 for population $\mathrm{C}$. AMOVA indicated that $88 \%$ of variance in the

Table 2. Genetic diversity parameters calculated for 90 accessions of rosewood, Aniba rosaeodora, from eight localities in the Peruvian Amazon, using 11 polymorphic ISSR primers.

\begin{tabular}{cccccccccc}
\hline Primer & TB & PB & $\begin{array}{c}\text { Polymorphism } \\
(\%)\end{array}$ & PIC & Ne & I & He & Ht \\
\hline 807 & 31 & 31 & 100 & 0.765 & 1.538 & 0.319 & 0.484 & 0.310 \\
\hline 810 & 42 & 39 & 92.9 & 0.726 & 1.466 & 0.278 & 0.427 & 0.258 \\
\hline 812 & 38 & 38 & 100 & 0.819 & 1.608 & 0.356 & 0.532 & 0.254 \\
814 & 33 & 33 & 100 & 0.844 & 1.477 & 0.302 & 0.470 & 0.270 \\
\hline 815 & 37 & 37 & 100 & 0.727 & 1.469 & 0.284 & 0.435 & 0.274 \\
\hline 817 & 29 & 29 & 100 & 0.727 & 1.435 & 0.274 & 0.433 & 0.274 \\
\hline 818 & 29 & 29 & 100 & 0.837 & 1.435 & 0.269 & 0.421 & 0.218 \\
\hline 819 & 10 & 10 & 100 & 0.592 & 1.605 & 0.351 & 0.524 & 0.233 \\
\hline 826 & 51 & 51 & 100 & 0.746 & 1.439 & 0.271 & 0.423 & 0.218 \\
\hline 834 & 37 & 37 & 100 & 0.867 & 1.431 & 0.271 & 0.427 & 0.258 \\
\hline 840 & 41 & 41 & 100 & 0.863 & 1.427 & 0.261 & 0.406 & 0.204 \\
\hline Average & 34.4 & 34.1 & 99.4 & 0.774 & 1.485 & 0.294 & 0.453 & 0.252 \\
\hline Total & 378 & 375 & & & & & & \\
\hline 8
\end{tabular}

TB: total bands, PB: polymorphic bands, PIC: polymorphism information content, Ne: effective allele number, I: Shannon information index, He: gene diversity, Ht: overall gene diversity 


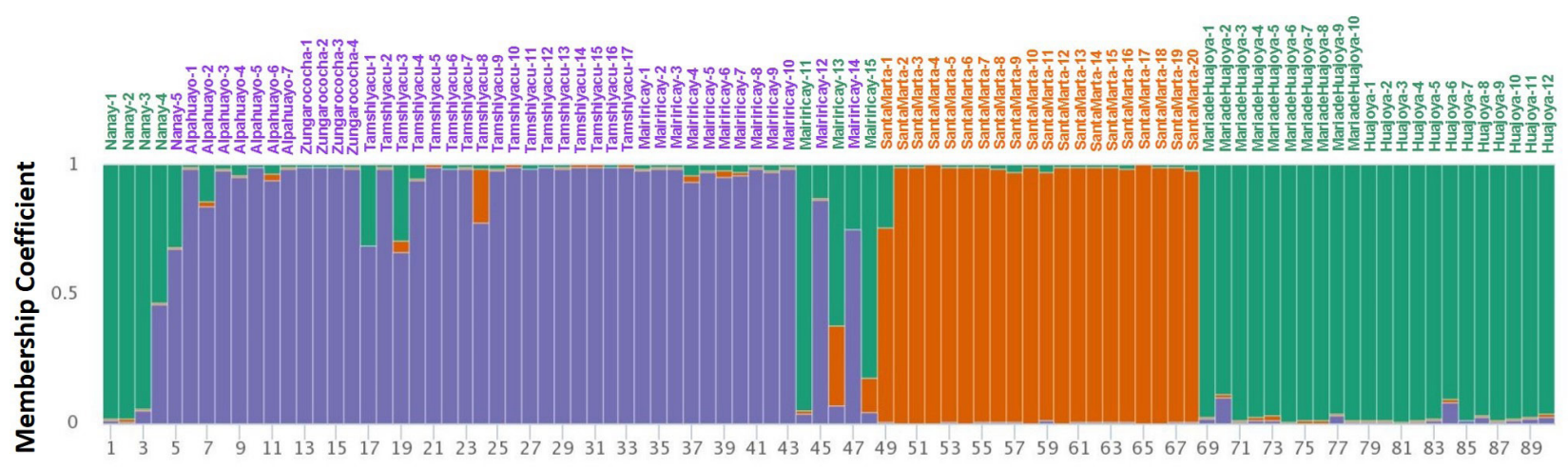

\section{Rosewood accessions}

\section{Population A Population B $\square$ Population C}

Figure 2. Population structure of 90 accessions of rosewood, Aniba rosaeodora from the Peruvian Amazon revealed by 11 ISSR primers. This figure is in color in the electronic version.

Peruvian rosewood accessions occurred within populations, and $12 \%$ among populations (Table 4 ).

The neighbor-joining-based clustering also grouped the 90 accessions into three populations (Figure 3). Neighbor joining based on the STRUCTURE populations grouped population $\mathrm{A}$ and $\mathrm{B}$, while population $\mathrm{C}$ was found genetically distinct from the other two (Figure 4). PCoA clearly supported the results obtained through neighbor joining and grouped the 90 accessions into three main clusters (Figure 5).

\section{DISCUSSION}

To our best knowledge, this is the first study to assess the genetic diversity and population structure of Peruvian rosewood accessions using ISSR primers. We found a higher mean number of bands per primer than that found by Angrizani et al. (2013) using 11 SSR primers in 68 rosewood accessions from two localities in the central Amazon in Brazil. We also obtained higher mean polymorphism than that reported by Santos et al. (2008a) for one locality in the central Brazilian Amazon using RAPD in 94 rosewood accessions. We found a higher PIC value than that reported by Ebrahimi et al. (2016) in Persian walnut, Juglans regia L. (Juglandaceae) germplasm and by Zhu et al. (2016)African, and Asian countries using SSR markers"," container-title":"Tree Genetics \& Genomes","page":"114","volume":"12","issue":"6","source ":"Springer Link","abstract":"Persian walnut (Juglans regia L. in Lindera glauca (Siebold \& Zucc.) Blume (Lauraceae) using SSR markers. We also found a higher number of effective alleles then that reported for three other Lauraceae species using ISSR markers (Zhang et al. 2012). The mean number of effective alleles in our samples was higher than in Nectandra megapotamica (Spreng.) Mezz (Lauraceae) from southern Brazil using RAPD markers (1.22 to 1.39) (Costa et al. 2015). A high number of effective alleles is always desirable, as this
Table 3. Diversity indices among the rosewood, Aniba rosaeodora populations from the Peruvian Amazon, as grouped by the STRUCTURE algorithm.

\begin{tabular}{cccccccc}
\hline Population & $\mathrm{Ne}$ & $\mathrm{He}$ & $\mathrm{I}$ & $\mathrm{Ht}$ & $\mathrm{Fst}$ & $\mathrm{Nm}$ & $\mathrm{GD}$ \\
\hline A & 1.447 & 0.271 & 0.416 & 0.219 & 0.08 & 2.875 & 0.362 \\
B & 1.420 & 0.256 & 0.393 & 0.228 & 0.16 & 1.313 & 0.323 \\
C & 1.367 & 0.219 & 0.335 & 0.173 & 0.29 & 0.612 & 0.314 \\
\hline
\end{tabular}

Ne: effective allele number, He: gene diversity, l: Shannon information index, Ht: overall gene diversity, Fst: measure of genetic structure, Nm: gene flow, GD: genetic distance

Table 4. Results for AMOVA among and within three rosewood, Aniba rosaeodora populations from the Peruvian Amazon as grouped by the cluster algorithm for 90 samples from eight localities.

\begin{tabular}{lccccc}
\hline Source of variance & df & SS & MS & $\begin{array}{c}\text { Estimated } \\
\text { variance }\end{array}$ & $\begin{array}{c}\% \\
\text { variations }\end{array}$ \\
\hline Among populations & 2 & 594.539 & 297.270 & 8.220 & 12 \\
Within populations & 87 & 5290.461 & 60.810 & 60.810 & 88 \\
Total & 89 & 5885.000 & & 69.030 & 100 \\
\hline
\end{tabular}

df: degrees of freedom, SS: Sum of squares, MS: Mean square

stands for high genetic diversity in a population (Ali et al. 2019), thus indicating a potential of high genetic variability in Peruvian rosewood accessions. We obtained a higher Shannon index then that reported for Neolitsea sericea (Blume) Koidz. (Lauraceae) using RAPD markers (Wang et al. 2005). As ISSR markers are more informative than RAPD markers (Verma et al. 2017), this suggests that our rosewood accessions were more diverse than the species of Lauraceae listed above, with a genetic variability more evenly distributed throughout the analyzed accessions. The gene diversity in our samples was also much higher than that reported for the Lauraceae, $N$. sericea 


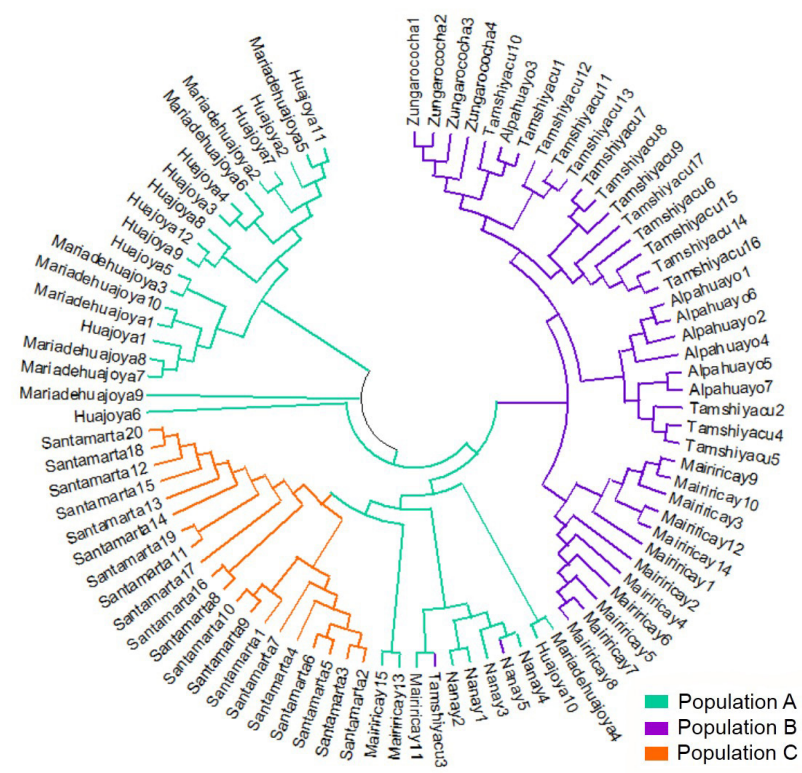

Figure 3. Neighbor-joining based clustering of 90 accessions of rosewood, Aniba rosaeodora from the Peruvian Amazon using 11 ISSR primers. This figure is in color in the electronic version.

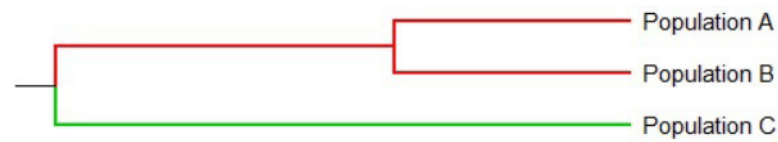

Figure 4. Neighbor-joining based clustering among rosewood, Aniba rosaeodora populations from the Peruvian Amazon using 11 ISSR primers. This figure is in color in the electronic version.
(Wang et al. 2005) and Lindera melissifolia (Walter) Blume (Godt and Hamrick 1996).

Endangered species usually have low genetic diversity, mainly due to genetic drift and inbreeding in small remnant populations (Spielman et al. 2004). Our results indicate a higher genetic diversity in rosewood in the Peruvian Amazon than the reported values for rosewood in the central Brazilian Amazon (Santos et al. 2008a; Angrizani et al. 2013). Santos et al. (2008b) studied the genetic variability of four rosewood populations in central Amazonia using RAPD markers, and found higher genetic variations in Ducke Reserve, the only population under long-term protection. The higher genetic diversity in Peru may be owed to higher gene flow among the populations, and/or to the environmental heterogeneity and complex topography in the Peruvian Amazon, compared to the central region of the Amazonas River floodplain. The conditions in the sub-Andean Amazon may have provided optimal refuge habitat for rosewood during past events of climate change, enabling the conservation of a higher level of genetic diversity (Morelli et al. 2016).

Our AMOVA results confirmed higher variability within (98.1\%) than among (1.9\%) rosewood populations. In the central Brazilian Amazon, Santos et al. (2008b) also found higher $(76.6 \%)$ genetic variations within $(76.6 \%)$ than among $(23.4 \%)$ populations in four populations of rosewood. The same pattern has also been reported in another tropical tree species in Belize (Pither et al. 2003). Similarly, Dong et al. (2016) studied the genetic diversity of five impacted and

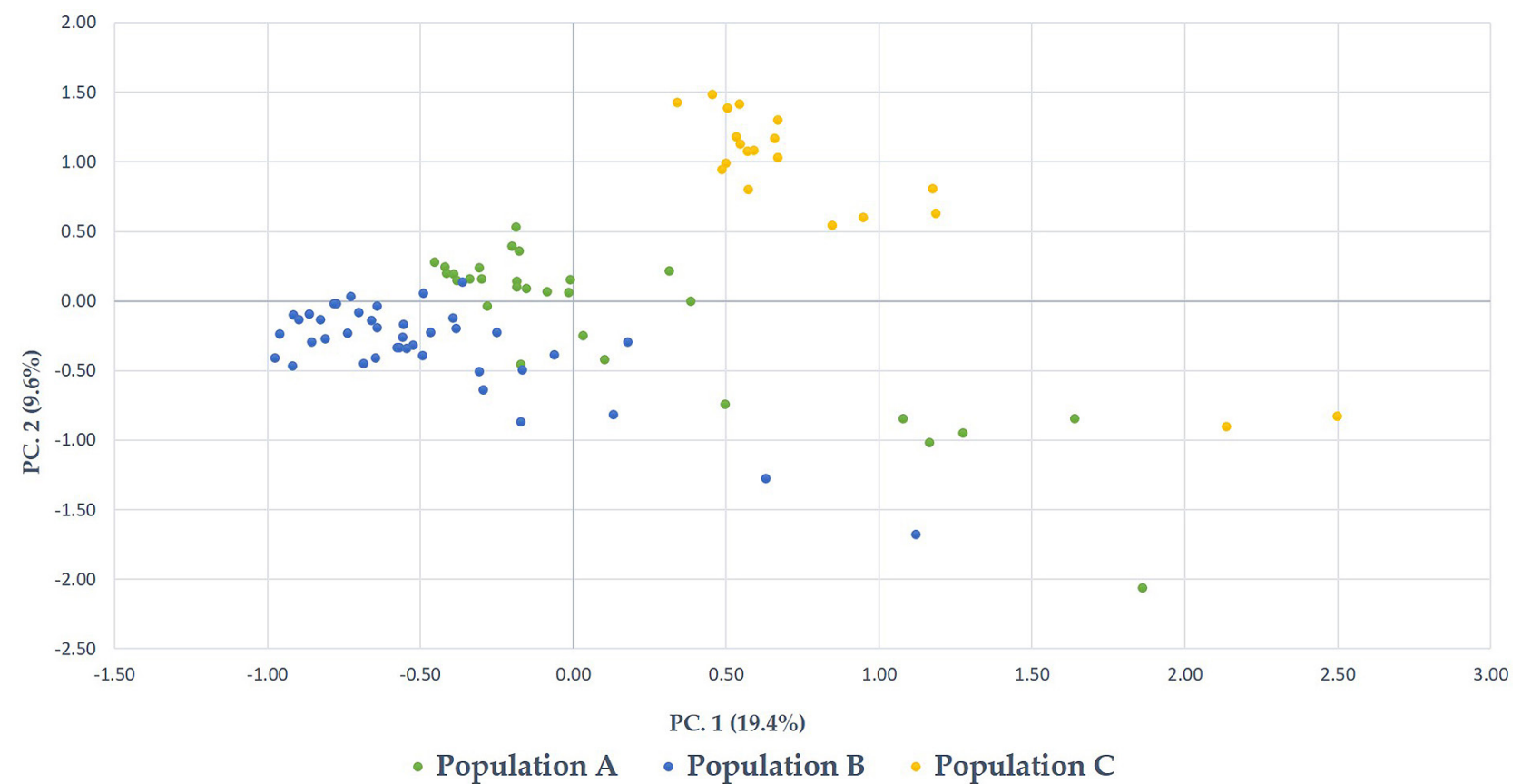

Figure 5. Principal coordinate analysis (PCOA) of rosewood, Aniba rosaeodora germplasm from the Peruvian Amazon revealed by 11 ISSR primers. This figure is in color in the electronic version. 
fragmented populations of the narrowly distributed and rare Cinnamomum chago B.S. Sun \& H.L. Zhao (Lauraceae) in a mountainous region in China using ISSR markers and found $17 \%$ of genetic variation among populations, and $83 \%$ within populations.

The STRUCTURE analysis separated more clearly the three populations $\mathrm{A}, \mathrm{B}$ and $\mathrm{C}$, as this software has better clustering power compared to other clustering algorithms. The differences with the neighbor joining clustering and PCoA might be due to their lower resolution power (Newell et al. 2013, Ali et al. 2019). In any case, accessions from the location of Santa Marta formed a distinct population, with lower genetic diversity, highest genetic distance and low gene flow respective to the other locations, which is likely related to the greater geographical distance and isolation of this stand from the other localities. Likewise, Santos et al. (2008b) found higher gene flow among rosewood populations closer to each other and also observed that increasing geographic distance resulted in decreased gene flow. Our population A, which had highest genetic diversity, grouped the wild populations of Nanay, Mariadehuajoya and Huajoya, indicating that frequent natural gene flow is maintained among these locations. Gene flow among populations conserves genetic diversity (Slatkin 1994), and high gene flow results in increased genetic diversity (Fu et al. 2016). The higher genetic similarity among the rosewood accessions grouped in population $\mathrm{B}$ of both clustering algorithms was expected, as those of Zunagarococha, Allpahuayo and Mairiricay were planted from material originating from the wild population of Tamshiyacu. Mairiircay was an interesting case, being a plantation, it was also grouped in population A, presumably because wild trees already existed in the area where the plantation was established, and/or part of the planted material was brought from population-A locations. Accessions Mairiricay-11 and Santamarta-4, which had maximum values of genetic distance are likely the more interesting for Peruvian rosewood breeding and conservation programs, as the evaluation of plants with variability in traits of interest is the main focus of breeders (Arystanbekkyzy et al. 2018).

\section{CONCLUSIONS}

Our genetic analysis of rosewood accessions from eight important remnant stands in the Peruvian Amazon revealed one distinct and more isolated population in the Ucayali region (Santa Marta). The populations at Zunagarococha, Allpahuayo and Mairiricay showed genetic similarity because they were planted from material originating from the wild population of Tamshiyacu. Genetic diversity in Peruvian rosewood germplasm was higher than that reported for rosewood populations in the central Brazilian Amazon, and higher within-population diversity is consistent with a pattern of fragmentation resulting from overexploitation.
The Peruvian accessions show promising potential for use in germplasm enhancement and parental selection in breeding and genetic improvement programs. Accessions Mairiricay-11 and Santamarta- 4 were found genetically distinct and can be suggested as candidate parents for rosewood breeding activities. This was the first attempt to investigate genetic diversity and population structure of Peruvian rosewood germplasm.

\section{ACKNOWLEDGMENTS}

The authors express their gratitude to Servicio Nacional Forestal y de Fauna Silvestre (SERFOR), Peru for providing the financial support for the collection of germplasm (1360-2018-MINAGRI-SERFOR-CAF). The authors also express their gratitude to Programa Nacional de Innovación Agraria (PNIA), Peru for providing a scientific internship to Stalin Juan Vasquez Guizado (156-2018-INIA-PNIA), at the Bolu Abant Izzet Baysal University, Bolu, Turkey.

\section{REFERENCES}

Ali, F.; Yılmaz, A.; Nadeem, M.A.; Habyarimana, E.; Subaşı, I.; Nawaz, M.A.; et al. 2019. Mobile genomic element diversity in world collection of safflower (Carthamus tinctorius L.) panel using iPBS-retrotransposon markers. PLOS ONE, 14: e0211985.

Ali, F.; Nadeem, M.A.; Barut, M.; Habyarimana, E.; Chaudhary, H.J.; Khalil, et al. 2020a. Genetic Diversity, Population Structure and Marker-Trait Association for 100-Seed Weight in International Safflower Panel Using SilicoDArT Marker Information. Plants, 9: doi.org/10.3390/plants9050652.

Ali, F.; Nadeem, M.A.; Habyarimana, E.; Yılmaz, A.; Nawaz, M.A.; Khalil, I.H.; et al. 2020b. Molecular characterization of genetic diversity and similarity centers of safflower accessions with ISSR markers. Brazilian Journal of Botany, 43: 109-121.

Amusant, N.; Beauchène, J.; Digeon, A.; Chaix, G. 2016. Essential oil yield in rosewood (Aniba Rosaeodora Ducke): initial application of rapid prediction by near infrared spectroscopy based on wood spectra. Journal of Near Infrared Spectroscopy, 24: 507-515.

Amusant, N.; Digeon, A.; Descroix, L.; Bruneau, O.; Bezard, V.; Beauchene, J. 2015. Planting rosewood for sustainable essential oil production: Influence of surrounding forest and seed provenance on tree growth and essential oil yields. Bois et Forest des Tropiques, 326: 57-65.

Angrizani, R.C.; Contim, L.A.S.; Lemes, M.R. 2013. Development and characterization of microsatellite markers for the endangered Amazonian tree Aniba rosaeodora (Lauraceae). Applications in Plant Sciences, 1: 1200516.

Arystanbekkyzy, M.; Nadeem, M.A.; Aktas, H.; Yeken, M.Z.; Zencirci, N.; Nawaz, M.A.; et al. 2018. Phylogenetic and taxonomic relationship of turkish wild and cultivated emmer (Triticum turgidum ssp. dicoccoides) revealed by iPBSretrotransposons markers. International Journal of Agriculture and Biology, 10: 1-9. 
Baloch, F.S.; Derya, M.; Andeden, E.E.; Alsaleh, A.; Cömertpay, G.; Kilian, B.; Özkan, H. 2015. Inter-primer binding site retrotransposon and inter-simple sequence repeat diversity among wild Lens species. Biochemical Systematics and Ecology, 58: 162-168.

Barut, M.; Nadeem, M.A.; Karaköy, T.; Baloch, F.S. 2020. DNA fingerprinting and genetic diversity analysis of world quinoa germplasm using iPBS-retrotransposon marker system. Turkish Journal of Agriculture and Forestry, 44: doi:10.3906/tar-2001-10

Bruleaux, A.M. 1989. Deux productions passées de la forêt guyanaise. L'essence de bois de rose et la gomme de balata. Bois \& Forets des Tropiques, 219: 99-113.

Cardoso, M.N.; Nascimento, A.L.S.; de Oliveira, L.A.R.; de Assunção, D.A.; Machado, C.A.; de Oliveira, A.C.A.; Muniz, A.D.S. 2019. Genetic diversity in native Genipa americana (Rubiaceae) populations in Sergipe, Brazil. Genetics and Molecular Research, 18: 1-19.

Castro, J.C.; Rodríguez, H.N.; Maddox, J.D.; Jiu, B.; Petterman, J.B.; Marapara, J.L.; Cobos, M. 2017. A simple and efficient method for high-quality total Rna isolation from oleaginous microalgae. Plant Cell Biotechnology and Molecular Biology, 18: $15-21$.

Confalonieri, U.E.; Margonari, C.; Quintão, A.F. 2014. Environmental change and the dynamics of parasitic diseases in the Amazon. Acta Tropica, 129: 33-41.

Contim, L.A.S.; Carvalho, C.R.; de Martins, F.A.; Freitas, D.V. 2005. Nuclear DNA content and karyotype of Rosewood (Aniba rosaeodora). Genetics and Molecular Biology, 28: 754-757.

Costa, L.S.; Reiniger, L.R.S.; Heinzmann, B.M.; Amaral, L.P.; Serrote, C.M. 2015. Study of the genetic diversity and structure of a natural population of Nectandra megapotamica (Spreng.) Mez. using RAPD markers. Genetics and Molecular Research, 14: 18407-18413.

Chantraine, J.M.; Dhénin, J.M.; Moretti, C. 2009. Chemical variability of rosewood (Aniba rosaeodora Ducke) essential oil in French Guiana. Journal of Essential Oil Research, 21: 486-495.

Dong, W.; Zhang, X.; Guansong, Y.; Yang, L.; Wang, Y.; Shen, S. 2016. Biological characteristics and conservation genetics of the narrowly distributed rare plant Cinnamomum chago (Lauraceae). Plant Diversity, 38: 247-252.

Ebrahimi, A.; Zarei, A.; Lawson, S.; Woeste, K.E.; Smulders, M.J.M. 2016. Genetic diversity and genetic structure of Persian walnut (Juglans regia) accessions from 14 European, African, and Asian countries using SSR markers. Tree Genetics \& Genomes, 12: 95-114.

Ekincialp, A.; Erdinc, C.; Turan, S.; Cakmakci, O.; Nadeem, M.A.; Shehzad, F.S. 2019. Genetic characterization of Rheum ribes L. (Wild Rhubarb) genotypes in Lake Van basin of Turkey through ISSR and SSR markers. International Journal of Agriculture and Biology. 21: 795-802.

Evanno, G.; Regnaut, S.; Goudet, J. 2005. Detecting the number of clusters of individuals using the software structure: a simulation study. Molecular Ecology, 14: 2611-2620.

Fu, P.C.; Gao, Q.B.; Zhang, F.Q.; Xing, R.; Wang, J.L.; Liu, H.R.; Chen, S.L. 2016. Gene flow results in high genetic similarity between Sibiraea (Rosaceae) species in the Qinghai-Tibetan Plateau. Frontiers in Plant Science, 7: 1596-1600.

Gentry, A.H. 1992. Tropical forest biodiversity: distributional patterns and their conservational significance. Oikos, 63: 19-28.

Godt, M.J.W.; Hamrick, J.L. 1996. Allozyme diversity in the endangered shrub Lindera melissifolia (Lauraceae) and its widespread congener Lindera benzoin. Canadian Journal of Forest Research, 26: 2080-2087.

González, A.; Souza, V.; Aguirre, X. 2007. Inter Simple Sequence Repeats (ISSRs). ASM Science Journal, 9: 567-571.

Habyarimana, E. 2016. Genomic prediction for yield improvement and safeguarding of genetic diversity in CIMMYT spring wheat (Triticum aestivum L.). Australian Journal of Crop Science, 10: 127-131.

Ibrahim, M.A.; Na, M.; Oh, J.; Schinazi, R.F.; McBrayer, T.R.; Whitaker, T.; et al. 2013. Significance of endangered and threatened plant natural products in the control of human disease. Proceedings of the National Academy of Sciences of the United States of America, 110: 16832-16837.

Jaccard, P. 1908. Nouvelles recherches sur la distribution florale. Bulletin de la Société Vaudoise des Sciences Naturelles, 44: 223-270.

Karik, U.; Nadeem, M.A.; Habyarimana, E.; Ercişli, S.; Yildiz, M.; Yilmaz, A.; Yang, S.H.; Chung, G.; Baloch, F.S. 2019. Exploring the genetic diversity and population structure of Turkish laurel germplasm by the iPBS-retrotransposon marker system. Agronomy. 9: 647, doi:10.3390/agronomy9100647.

Krainovic, P.; Almeida, D.; Sampaio, P. 2017. New allometric equations to support sustainable plantation management of rosewood (Aniba rosaeodora Ducke) in the Central Amazon. Forests, 8: 327, doi.org/10.3390/f8090327.

Maia, J.G.S.; Mourão, R.H.V. 2016. Amazon rosewood (Aniba rosaeodora Ducke) oils. In: Preedy, V.R. (Ed.). Essential Oils in Food Preservation, Flavor and Safety. Academic Press, New York, p.193-201.

Mallet, J. 1999. Gene flow. In: Woiwod, I.P.; Reynolds, D.R.; Thomas, C.D. (Ed.). Insect Movement: Mechanisms and Consequences. Symposium-Royal Entomological Society of London, CAB International, Wallingford, p.337-360.

MINAM. 2015. Dictamen de extracción no prejudicial de Aniba rosaeodora Ducke "palo de rosa" procedente del medio natural. Viceministerio de Desarrollo Estratégico de Recursos Naturales - Ministerio del Ambiente, Peru. 26p

Morelli, T.L.; Daly, C.; Dobrowski, S.Z.; Dulen, D.M.; Ebersole, J.L.; Jackson, S.T.; et al. 2016. Managing climate change refugia for climate adaptation. PLoS ONE, 11: e0169725.

Myers, N.; Mittermeier, R.A.; Mittermeier, C.G.; Da Fonseca, G.A.; Kent, J. 2000. Biodiversity hotspots for conservation priorities. Nature, 403: 845-853.

Nadeem, M.A.; Nawaz, M.A.; Shahid, M.Q.; Do ־gan, Y.; Comertpay, G.; Yıldız, M.; et al.. 2018. DNA molecular markers in plant breeding: Current status and recent advancements in genomic selection and genome editing. Biotechnology \& Biotechnological Equipment, 32: 261-285

Nadeem, M.A.; Gündoğdu, M.; Ercişli, S.; Karaköy, T.; Saracoğlu, O.; Habyarimana, E.; et al. 2020. Uncovering phenotypic 
diversity and DArTseq marker loci associated with antioxidant activity in common bean. Genes, 11: 36. doi.org/10.3390/ genes 11010036

Newell, M.A.; Cook, D.; Hofmann, H.; Jannink, J.L. 2013. An algorithm for deciding the number of clusters and validation using simulated data with application to exploring crop population structure. The Annals of Applied Statistics, 7: 18981916.

Peakall, R.; Smouse, P.E. 2012. GenAlEx 6.5: genetic analysis in Excel. Population genetic software for teaching and research-an update. Bioinformatics, 28: 2537-2539.

Pimentel, R.B.; Souza, D.P.; Albuquerque, P.M.; Fernandes, A.V.; Santos, A.S.; Duvoisin Jr,S.; Gonçalves, J.F. 2018. Variability and antifungal activity of volatile compounds from Aniba rosaeodora Ducke, harvested from Central Amazonia in two different seasons. Industrial Crops and Products, 123: 1-9.

Pither, R.; Shore, J.S.; Kellman, M. 2003. Genetic diversity of the tropical tree Terminalia amazonia (Combretaceae) in naturally fragmented populations. Heredity, 91: 307-313.

Salazar, B.M. 2011. List of Peruvian CITES Species Wild Flora. Ministerio del Ambiente, Lima, 130p.

Santos, A.S.; Antunes, A.M.S.; D'Avila, L.A. 2004. New natural linalol sources: research and industrial application. Perfumer \& Flavorist, 29: 38-43.

Santos, R.P.; Spironello, W.R.; Sampaio, P.T.B. 2008a. Genetic diversity in rosewood saplings (Aniba rosaeodora Ducke, Lauraceae): an ecological approach. Acta Amazonica, 38: 707714.

Santos, R.P.; Ângelo, P.C.D.S.; Sampaio, P.D.T.B.; Quisen, R.C.; Leite, Â.M.C.; Oliveira, C.L.D. 2008b. Geographic pattern of genetic diversity in natural populations of Rosewood (Aniba rosaeodora), in the Central Amazonia. Acta Amazonica, 38: 459-466.

Sarrazin, S.L.F.; Oliveira, R.B.; Maia, J.G.S.M.; Mourão, R.H.V. 2016. Antibacterial activity of the rosewood (Aniba rosaeodora and $A$. parviflora) linalool-rich oils from the Amazon. European Journal of Medicinal Plants. 12: 1-9.

Slatkin, M. 1994. Gene flow and population structure. Ecological Genetics, 1: 3-17.
Spielman, D.; Brook, B.W.; Briscoe, D.A.; Frankham, R. 2004. Does inbreeding and loss of genetic diversity decrease disease resistance? Conservation Genetics, 5: 439-448.

Tabin, S.; Kamili, A.N.; Ganie, S.A.; Zargar, O.; Sharma, V.; Gupta, R.C. 2016. Genetic diversity and population structure of Rheum species in Kashmir Himalaya based on ISSR markers. Flora, 223: $121-128$.

Verma, K.S.; ul Haq, S.; Kachhwaha, S.; Kothari, S.L. 2017. RAPD and ISSR marker assessment of genetic diversity in Citrullus colocynthis (L.) Schrad: a unique source of germplasm highly adapted to drought and high-temperature stress. 3 Biotech, 7: 288. doi: 10.1007/s13205-017-0918-z.

Wang, Z.S.; An, S.Q.; Liu, H.; Leng, X.; Zheng, J.W.; Liu, Y.H. 2005. Genetic structure of the endangered plant Neolitsea sericea (Lauraceae) from the Zhoushan Archipelago using RAPD markers. Annals of Botany. 95: 305-313.

Yaldiz, G.; Çamlica, M.; Nadeem, M.A.; Nawaz, M.A.; Baloch, F.S. 2018. Genetic diversity assessment in Nicotiana tabacum L. with iPBS-retrotransposons. Turkish Journal of Agriculture and Forestry, 42: 154-164.

Yildiz, M.; Koçak, M.; Nadeem, M.A.; Cavagnaro, P.; Barboza, K.; Baloch, F.S.; Argün, D.; Keleş, D. 2019. Genetic diversity analysis in the Turkish pepper germplasm using iPBS retrotransposon-based markers. Turkish Journal of Agriculture and Forestry, 44: 1-14.

Zhang, R.; Zhou, Z.; Jin, G.; Wang, S.; Wang, X. 2012. Genetic diversity and differentiation within three species of the family Lauraceae in southeast China. Biochemical Systematics and Ecology, 44: 317-324.

Zhu, S.; Ding, Y.; Yap, Z.; Qiu, Y. 2016. De novo assembly and characterization of the floral transcriptome of an economically important tree species, Lindera glauca (Lauraceae), including the development of EST-SSR markers for population genetics. Molecular Biology Reports, 43: 1243-1250.

RECEIVED: $27 / 06 / 2019$
ACCEPTED: 22/06/2020
ASSOCIATE EDITOR: Alexandre Pio Viana


SUPPLEMENTARY MATERIAL (only available in the electronic version)

Guizado et al. Genetic diversity and population structure of endangered rosewood from the Peruvian Amazon using ISSR markers

Table S1. Passport data of 90 rosewood, Aniba rosaeodora accessions collected from eight different localities in the Peruvian Amazon (see Figure 1).

\begin{tabular}{|c|c|c|c|c|c|c|c|c|}
\hline Serial. Nr. & Accession name & Region & Province & District & Village & Latitude & Longitude & $\begin{array}{c}\text { Altitude } \\
\text { (m) }\end{array}$ \\
\hline 1 & Nanay-1 & Loreto & Alto Nanay & Santa maria del Nanay & Quebrada Curaca & 9551691 & 638610 & 152 \\
\hline 2 & Nanay-2 & Loreto & Alto Nanay & Santa maria del Nanay & Santa maria del nanay & 9569683 & 644419 & 106 \\
\hline 3 & Nanay-3 & Loreto & Alto Nanay & Santa maria del Nanay & Santa maria del nanay & 9569689 & 644389 & 109 \\
\hline 4 & Nanay-4 & Loreto & Alto Nanay & Santa maria del Nanay & Santa maria del nanay & 9569727 & 644387 & 106 \\
\hline 5 & Nanay-5 & Loreto & Alto Nanay & Santa maria del Nanay & Santa maria del nanay & 9569721 & 644391 & 99 \\
\hline 6 & Allpahuayo-1 & Loreto & Maynas & San Juan Bautista & Allpahuayo & 9561154 & 675470 & 158 \\
\hline 7 & Allpahuayo-2 & Loreto & Maynas & San Juan Bautista & Allpahuayo & 9561182 & 675477 & 148 \\
\hline 8 & Allpahuayo-3 & Loreto & Maynas & San Juan Bautista & Allpahuayo & 9561208 & 675492 & 144 \\
\hline 9 & Allpahuayo-4 & Loreto & Maynas & San Juan Bautista & Allpahuayo & 9561236 & 675505 & 148 \\
\hline 10 & Allpahuayo-5 & Loreto & Maynas & San Juan Bautista & Allpahuayo & 9561247 & 675500 & 142 \\
\hline 11 & Allpahuayo-6 & Loreto & Maynas & San Juan Bautista & Allpahuayo & 9561262 & 675512 & 141 \\
\hline 12 & Allpahuayo-7 & Loreto & Maynas & San Juan Bautista & Allpahuayo & 9561300 & 675527 & 138 \\
\hline 13 & Zungarococha-1 & Loreto & Maynas & San Juan Bautista & Zungarococha & 9576628 & 681106 & 113 \\
\hline 14 & Zungarococha-2 & Loreto & Maynas & San Juan Bautista & Zungarococha & 9576631 & 681105 & 115 \\
\hline 15 & Zungarococha-3 & Loreto & Maynas & San Juan Bautista & Zungarococha & 9576625 & 681115 & 116 \\
\hline 16 & Zungarococha-4 & Loreto & Maynas & San Juan Bautista & Zungarococha & 9576650 & 681100 & 114 \\
\hline 17 & Tamshiyacu-1 & Loreto & Maynas & Fernando Lores & Tamshiyacu & 9559735 & 706059 & 112 \\
\hline 18 & Tamshiyacu-2 & Loreto & Maynas & Fernando Lores & Tamshiyacu & 9559801 & 706144 & 110 \\
\hline 19 & Tamshiyacu-3 & Loreto & Maynas & Fernando Lores & Tamshiyacu & 9559783 & 706148 & 120 \\
\hline 20 & Tamshiyacu-4 & Loreto & Maynas & Fernando Lores & Tamshiyacu & 9559741 & 706087 & 123 \\
\hline 21 & Tamshiyacu-5 & Loreto & Maynas & Fernando Lores & Tamshiyacu & 9559669 & 706071 & 111 \\
\hline 22 & Tamshiyacu-6 & Loreto & Maynas & Fernando Lores & Tamshiyacu & 9560651 & 705900 & 125 \\
\hline 23 & Tamshiyacu-7 & Loreto & Maynas & Fernando Lores & Tamshiyacu & 9560660 & 705877 & 105 \\
\hline 24 & Tamshiyacu-8 & Loreto & Maynas & Fernando Lores & Tamshiyacu & 9560676 & 705862 & 116 \\
\hline 25 & Tamshiyacu-9 & Loreto & Maynas & Fernando Lores & Tamshiyacu & 9560681 & 705840 & 121 \\
\hline 26 & Tamshiyacu-10 & Loreto & Maynas & Fernando Lores & Tamshiyacu & 9559356 & 706026 & 119 \\
\hline 27 & Tamshiyacu-11 & Loreto & Maynas & Fernando Lores & Tamshiyacu & 9559220 & 706283 & 129 \\
\hline 28 & Tamshiyacu-12 & Loreto & Maynas & Fernando Lores & Tamshiyacu & 9559223 & 706274 & 112 \\
\hline 29 & Tamshiyacu-13 & Loreto & Maynas & Fernando Lores & Tamshiyacu & 9559205 & 706296 & 115 \\
\hline 30 & Tamshiyacu-14 & Loreto & Maynas & Fernando Lores & Tamshiyacu & 9559076 & 706243 & 108 \\
\hline 31 & Tamshiyacu-15 & Loreto & Maynas & Fernando Lores & Tamshiyacu & 9559096 & 706281 & 119 \\
\hline 32 & Tamshiyacu-16 & Loreto & Maynas & Fernando Lores & Tamshiyacu & 9559092 & 706266 & 115 \\
\hline 33 & Tamshiyacu-17 & Loreto & Maynas & Fernando Lores & Tamshiyacu & 9559076 & 706269 & 110 \\
\hline 34 & Mairiricay-1 & Loreto & Putumayo & Putumayo & Mairiricay & 9726985 & 760695 & 136 \\
\hline 35 & Mairiricay-2 & Loreto & Putumayo & Putumayo & Mairiricay & 9726991 & 760701 & 132 \\
\hline 36 & Mairiricay-3 & Loreto & Putumayo & Putumayo & Mairiricay & 9726988 & 760714 & 134 \\
\hline 37 & Mairiricay-4 & Loreto & Putumayo & Putumayo & Mairiricay & 9727009 & 760707 & 132 \\
\hline 38 & Mairiricay-5 & Loreto & Putumayo & Putumayo & Mairiricay & 9727008 & 760702 & 131 \\
\hline 39 & Mairiricay-6 & Loreto & Putumayo & Putumayo & Mairiricay & 9726999 & 760690 & 130 \\
\hline 40 & Mairiricay-7 & Loreto & Putumayo & Putumayo & Mairiricay & 9726978 & 760714 & 125 \\
\hline 41 & Mairiricay-8 & Loreto & Putumayo & Putumayo & Mairiricay & 9726981 & 760726 & 126 \\
\hline 42 & Mairiricay-9 & Loreto & Putumayo & Putumayo & Mairiricay & 9726972 & 760715 & 125 \\
\hline 43 & Mairiricay-10 & Loreto & Putumayo & Putumayo & Mairiricay & 9726971 & 760716 & 127 \\
\hline
\end{tabular}


Table S1. Continued.

\begin{tabular}{|c|c|c|c|c|c|c|c|c|}
\hline Serial. Nr. & Accession name & Region & Province & District & Village & Latitude & Longitude & $\begin{array}{c}\text { Altitude } \\
\text { (m) }\end{array}$ \\
\hline 44 & Mairiricay-11 & Loreto & Putumayo & Putumayo & Mairiricay & 9726971 & 760713 & 123 \\
\hline 45 & Mairiricay-12 & Loreto & Putumayo & Putumayo & Mairiricay & 9726982 & 760719 & 128 \\
\hline 46 & Mairiricay-13 & Loreto & Putumayo & Putumayo & Mairiricay & 9727003 & 760729 & 124 \\
\hline 47 & Mairiricay-14 & Loreto & Putumayo & Putumayo & Mairiricay & 9726994 & 760726 & 126 \\
\hline 48 & Mairiricay-15 & Loreto & Putumayo & Putumayo & Mairiricay & 9727007 & 760725 & 124 \\
\hline 49 & Santamarta-1 & Ucayali & Atalaya & Masisea & Santa Marta & 8980940 & 604385 & 171 \\
\hline 50 & Santamarta-2 & Ucayali & Atalaya & Masisea & Santa Marta & 8980933 & 604388 & 169 \\
\hline 51 & Santamarta-3 & Ucayali & Atalaya & Masisea & Santa Marta & 8980925 & 604386 & 170 \\
\hline 52 & Santamarta-4 & Ucayali & Atalaya & Masisea & Santa Marta & 8980934 & 604388 & 169 \\
\hline 53 & Santamarta-5 & Ucayali & Atalaya & Masisea & Santa Marta & 8980923 & 604387 & 172 \\
\hline 54 & Santamarta-6 & Ucayali & Atalaya & Masisea & Santa Marta & 8980943 & 604348 & 171 \\
\hline 55 & Santamarta-7 & Ucayali & Atalaya & Masisea & Santa Marta & 8981608 & 604180 & 171 \\
\hline 56 & Santamarta-8 & Ucayali & Atalaya & Masisea & Santa Marta & 8981590 & 604184 & 171 \\
\hline 57 & Santamarta-9 & Ucayali & Atalaya & Masisea & Santa Marta & 8981587 & 604200 & 173 \\
\hline 58 & Santamarta-10 & Ucayali & Atalaya & Masisea & Santa Marta & 8981586 & 604182 & 171 \\
\hline 59 & Santamarta-11 & Ucayali & Atalaya & Masisea & Santa Marta & 8981588 & 604231 & 174 \\
\hline 60 & Santamarta-12 & Ucayali & Atalaya & Masisea & Santa Marta & 8981574 & 604258 & 176 \\
\hline 61 & Santamarta-13 & Ucayali & Atalaya & Masisea & Santa Marta & 8981667 & 604622 & 174 \\
\hline 62 & Santamarta-14 & Ucayali & Atalaya & Masisea & Santa Marta & 8981668 & 604623 & 174 \\
\hline 63 & Santamarta-15 & Ucayali & Atalaya & Masisea & Santa Marta & 8981674 & 604632 & 175 \\
\hline 64 & Santamarta-16 & Ucayali & Atalaya & Masisea & Santa Marta & 8981978 & 604874 & 177 \\
\hline 65 & Santamarta-17 & Ucayali & Atalaya & Masisea & Santa Marta & 8981965 & 604878 & 175 \\
\hline 66 & Santamarta-18 & Ucayali & Atalaya & Masisea & Santa Marta & 8981959 & 604892 & 175 \\
\hline 67 & Santamarta-19 & Ucayali & Atalaya & Masisea & Santa Marta & 8981528 & 604688 & 172 \\
\hline 68 & Santamarta-20 & Ucayali & Atalaya & Masisea & Santa Marta & 8980586 & 604483 & 164 \\
\hline 69 & Mariadehuajoya-1 & Loreto & Maynas & Napo & Maria de Huajoya & 9838429 & 536797 & 120 \\
\hline 70 & Mariadehuajoya-2 & Loreto & Maynas & Napo & Maria de Huajoya & 9835376 & 537866 & 125 \\
\hline 71 & Mariadehuajoya-3 & Loreto & Maynas & Napo & Maria de Huajoya & 9833880 & 535209 & 116 \\
\hline 72 & Mariadehuajoya-4 & Loreto & Maynas & Napo & Maria de Huajoya & 9835834 & 531637 & 121 \\
\hline 73 & Mariadehuajoya-5 & Loreto & Maynas & Napo & Maria de Huajoya & 9838277 & 528614 & 118 \\
\hline 74 & Mariadehuajoya-6 & Loreto & Maynas & Napo & Maria de Huajoya & 9841544 & 530843 & 118 \\
\hline 75 & Mariadehuajoya-7 & Loreto & Maynas & Napo & Maria de Huajoya & 9839223 & 533377 & 123 \\
\hline 76 & Mariadehuajoya-8 & Loreto & Maynas & Napo & Maria de Huajoya & 9838429 & 535515 & 140 \\
\hline 77 & Mariadehuajoya-9 & Loreto & Maynas & Napo & Maria de Huajoya & 9841788 & 535393 & 135 \\
\hline 78 & Mariadehuajoya-10 & Loreto & Maynas & Napo & Maria de Huajoya & 9840811 & 537164 & 129 \\
\hline 79 & Huajoya-1 & Loreto & Maynas & Napo & Huajoya & 9852750 & 540889 & 146 \\
\hline 80 & Huajoya-2 & Loreto & Maynas & Napo & Huajoya & 9851987 & 543454 & 152 \\
\hline 81 & Huajoya-3 & Loreto & Maynas & Napo & Huajoya & 9852140 & 545255 & 134 \\
\hline 82 & Huajoya-4 & Loreto & Maynas & Napo & Huajoya & 9854918 & 544828 & 142 \\
\hline 83 & Huajoya-5 & Loreto & Maynas & Napo & Huajoya & 9855834 & 543179 & 127 \\
\hline 84 & Huajoya-6 & Loreto & Maynas & Napo & Huajoya & 9855010 & 539087 & 131 \\
\hline 85 & Huajoya-7 & Loreto & Maynas & Napo & Huajoya & 9854949 & 537744 & 135 \\
\hline 86 & Huajoya-8 & Loreto & Maynas & Napo & Huajoya & 9856109 & 539912 & 145 \\
\hline 87 & Huajoya-9 & Loreto & Maynas & Napo & Huajoya & 9855651 & 543576 & 155 \\
\hline 88 & Huajoya-10 & Loreto & Maynas & Napo & Huajoya & 9854430 & 544858 & 149 \\
\hline 89 & Huajoya-11 & Loreto & Maynas & Napo & Huajoya & 9852873 & 547362 & 138 \\
\hline 90 & Huajoya-12 & Loreto & Maynas & Napo & Huajoya & 9851040 & 546660 & 151 \\
\hline
\end{tabular}

